\title{
KNOWLEDGE LEVEL REGARDING JUNK FOOD CONSUMPTION AMONG SCHOOL CHILDREN IN DHARWAD DISTRICT, KARNATAKA
}

\author{
Sylvia Borgis 1 \\ ${ }^{1} \mathrm{PhD}$ Scholar, \\ Department of Food Science and Nutrition, \\ College of Community Science, \\ University of Agricultural Sciences, \\ Dharwad- 580 005, \\ Karnataka, India
}

\author{
Mahalakshmi B Kandakur ${ }^{2}$ \\ ${ }^{2} \mathrm{PhD}$ Scholar, \\ Department of Food Science and Nutrition, \\ College of Community Science, \\ University of Agricultural Sciences, \\ Dharwad- 580 005, \\ Karnataka, India
}

\author{
Pushpa Bharati ${ }^{3}$ \\ ${ }^{3}$ Professor, \\ Department of Food Science and Nutrition, \\ College of Community Science, \\ University of Agricultural Sciences, \\ Dharwad- 580 005, \\ Karnataka, India
}

Article DOI: https://doi.org/10.36713/epra5582

\begin{abstract}
Junk foods have gained rapid popularity as they are easily available, ready to eat or served ready to eat as fast foods. Additives used in junk food make them more appealing and palatable which in-turn encourages consumption. Junk foods are known to cause adverse health effects like obesity, hyperglycemia, hypertension, dyslipidemia etc., yet it is widely consumed especially among the adolescents. A study was undertaken with the objective to assess the knowledge level regarding junk food consumption among school children in Dharwad district. Schools selected were Narendra School in rural area and Krishinagar school in urban area. Random sampling technique was employed for selection of the samples. A total of 120 students $\left(60\right.$ each school) studying in class $7^{\text {th }}, 8^{\text {th }}, 9^{\text {th }}$ and $10^{\text {th }}$ were selected. Each subject was asked to fill the questionnaire. Subjects belonged to age group of 13 - 16 years. Family occupation among most of the subjects was agriculture and the family income was less than Rs. 1 lakh per annum. Breakfast was consumed at home and lunch was provided at school under mid-day meal scheme. Food outlets available nearby were petty shops, canteen, bakery, grocery stores and hotels. Majority of subjects 36 (60.00\%) from Narendra and 46 (76.67\%) Krishinagar were knowing about junk foods but knowledge regarding various ingredients, preservatives and chemicals used in preparation of junk foods and their adverse health effects was limited. Junk food consumption among most of the subjects was on monthly basis that is 21 (35.00\%) from Narendra and 17 (28.33\%) from Krishinagar. Commonly consumed junk food were deep fried items like chips, namkeens, sweets and other items like toffees, candies and coloured ice candies. Hence there is a need create awareness and impart knowledge regarding junk food and its effect on health among school children.
\end{abstract}

KEY WORDS: Junk foods, fast foods, preservatives, chemicals, health.

\section{INTRODUCTION}

Junk food culture has a vigorously uprising trend among youngsters and it makes people eat without planning. Fast food refers to food that can be served ready to eat. The terms fast food and junk food are often used interchangeably. Most of the junk foods are fast foods as they are prepared and served fast, but not all fast foods are junk foods, especially when they are prepared with nutritious contents (Kaushik et al., 2011). The definition of various food 
items: fast foods are rapidly prepared and quickly served in a packaged form for take away eg: burgers, pizzas, fries, Indian foods like pakora, samosa, namkeen etc. Junk foods are energy dense foods with high sugar/ fat/ salt content and low nutrient value eg: chips, chocolate, ice-cream, soft drinks, burgers, pizzas etc.

The ready availability, taste, low cost, marketing strategies and peer pressure make them popular with children and adolescents. Fast food sale is promoted among children mainly through advertisements. Fast food chains are gaining popularity with nuclear families as working parents have less time for meal preparation at home. Junk foods are widely available in schools through variety of outlets. Consumption of diet high in sugar, saturated fat, salt and calorie content in children can lead to early development of obesity, hypertension, dyslipidemia and impaired glucose tolerance (Printice and Jebb, 2003). The concerns with fast food consumption also include poor hygiene during preparation storage and handling leading to microbiological contamination. Fast foods have high content of trans fat which predispose children to risk of future heart diseases (Asgary et al., 2009). Energy density of fast food is more than twice the recommended daily allowance for children. Junk foods often contain colors that are inedible, carcinogenic and harmful to the body. Food coloring may result in hyperactivity and lapses of concentration in children. Poor nutritional habits can undermine these pre-requisites of learning, as well as decrease the strength that children need for better future foundation. Hence the present study was undertaken with the objective to assess the knowledge level regarding junk food consumption among school children.

\section{MATERIALS AND METHODS}

Selection of the sample: The study was conducted in Dharwad District, Karnataka. Two schools that is Government School of Narendra, Narendra taluk and Krishinagar Government School, Krishinagar of Dharwad District were selected for the study. Sixty subjects from each school studying in class $7^{\text {th }}, 8^{\text {th }}, 9^{\text {th }}$ and $10^{\text {th }}$ were selected for the study. Random Sampling Technique was employed and the total sample size was 120 .

Development of Questionnaire: The questionnaire consisting general information, availability, knowledge level and frequency of consumption of junk food was structured. Great care was taken to see that the questions were unambiguous, clear, complete and comprehensive. The questionnaire was prepared in conformity with the objective of the study.

Method of data collection: The total 120 subjects (60 subjects from each school) were asked to fill the questionnaire. They were asked to describe personal details, availability of junk food and type of junk foods consumed. Subjects were asked to tick Yes/No for knowledge whereas for consumption they were asked to tick frequency. Frequency and percentage were calculated for knowledge level and consumption of junk food.

\section{RESULTS AND DISCUSSION}

Table 1 Socio-Demographic profile of school children

\begin{tabular}{|c|l|c|c|}
\hline SI No & Demographic profile & Narendra School & Krishinagar School \\
\hline 1 & Age & $13-16$ years & $13-16$ years \\
\hline 2 & Family size & $3-8$ members & $3-6$ members \\
\hline \multirow{2}{*}{3} & Occupation of family head & & $29(48.33 \%)$ \\
\hline \multirow{2}{*}{} & Agriculture & $41(68.33 \%)$ & $31(51.67 \%)$ \\
\cline { 2 - 4 } & Non agriculture & $19(31.67 \%)$ & Low $(<1$ Lakh/annum $)$ \\
\hline 4 & Family Income (annual) & Low $(<$ Rs.84,000/annum) &
\end{tabular}

Table 1 depicts socio-demographic profile of subjects studying Narendra Village and Krishinagar, Dharwad District. The age of subjects ranged between 13 to 16 years. The family size of subjects from Narendra rural area was 3 to 8 members, whereas those from Krishinagar urban area was 3 to 6 members. Families of subjects residing in rural area of Narendra had agriculture as main occupation $41(68.33 \%)$ and 29 $(48.33 \%)$ of families of subjects from Krishinagar also had agriculture as occupation. Though Krishinagar school was situated in urban area, students from nearby village also attended school. Family annual income of the subjects from both school of Narendra and Krishinagar was less than Rs.84,000/- and Rs. 1 lakh respectively. 
Table 2 Availability of food outlets and meal consumption of subjects

\begin{tabular}{|c|c|c|c|}
\hline SI No & School details & Narendra School & Krishinagar School \\
\hline 1 & Availability of food outlets & & \\
\hline i. & School & Petty Shops, bakery & Canteen, bakery \\
\hline ii. & Home & Petty Shops, canteen & Canteen, petty shops \\
\hline iii. & On the way & Bakery & Petty shops, hotels \\
\hline 2 & Consumption of breakfast at home & Yes & Yes \\
\hline 3 & Carrying lunch box to school & No & No \\
\hline 4 & Mid-day meal at school & Yes & Yes \\
\hline
\end{tabular}

Table 2 depicts availability of food outlets and meal consumption of subjects. In Narendra the subjects stated that the food outlets available nearby school, home and on the way were petty shops, canteen and bakery whereas those available at Krishinagar were bakery, canteen, grocery stores, petty shops and hotels. These shops are common in rural areas and also in surrounding area of schools. Breakfast was consumed compulsorily at home as suggested by parents and subjects wanted to be energetic in school. They did not carry any lunch box to school as lunch was provided under mid-day meal scheme.

Table 3 Knowledge level regarding junk food among the subjects

$\mathbf{N}=\mathbf{1 2 0}$

\begin{tabular}{|r|l|c|c|}
\hline \multirow{2}{*}{$\begin{array}{l}\text { Sl } \\
\text { No }\end{array}$} & \multicolumn{1}{|c|}{ Question } & \multicolumn{2}{|c|}{ Knowledge level } \\
\cline { 3 - 4 } & & Narendra & Krishinagar \\
\hline 1. & Have you heard about the junk foods? & $36(60.00 \%)$ & $46(76.67 \%)$ \\
\hline 2. & Do you think it is harmful? & $24(40.00 \%)$ & $38(63.33 \%)$ \\
\hline 3. & Do you think it makes a person unhealthy/overweight? & $36(60.00 \%)$ & $32(53.33 \%)$ \\
\hline 4. & Do you think that junk food is convenient and cheap alternative to & $30(50.00 \%)$ & $16(26.67 \%)$ \\
\hline h. & Domemade food? & $2(3.33 \%)$ & $22(36.67 \%)$ \\
\hline 6. & Do you know about ingredients used in junk foods? & $14(23.33 \%)$ & $24(40.00 \%)$ \\
\hline 7. & Have you heard about ajinomoto? & $20(33.33 \%)$ & $25(41.67 \%)$ \\
\hline 8. & Do you know about the food preservatives? & $24(40.00 \%)$ & $18(30.00 \%)$ \\
\hline 9. & Do you know about empty calories? & $8(13.33 \%)$ & $18(30.00 \%)$ \\
\hline 10. & $\begin{array}{l}\text { Do you know the harmful effects of chemicals present in junk } \\
\text { food? }\end{array}$ & $12(20.00 \%)$ & $15(25.00 \%)$ \\
\hline 11. & Do toxins in junk food affect nutrient absorption? & $4(6.67 \%)$ & $10(16.67 \%)$ \\
\hline 12. & Does advertisement affect your junk food consumption? & $48(80.00 \%)$ & $32(53.33 \%)$ \\
\hline 13. & Is food, nutrition and health inter-related? & $48(80.00 \%)$ & $36(60.00 \%)$ \\
\hline
\end{tabular}

Frequency (percentage) - Subjects who answered YES

Table 3 depicts knowledge level regarding junk food among the subjects. Majority of subjects that is $36(60.00 \%)$ from rural Narendra and 46 (76.67\%) from urban Krishinagar knew about junk foods. Subjects from Narendra $48(80.00 \%)$ and Krishinagar $36(60.00 \%)$ were also aware that food, nutrition and health are inter-related but knowledge regarding various ingredients, preservatives and chemicals used in preparation of junk foods and their adverse health effects regarding consumption of junk food was less. This may be due to lack of nutrition knowledge. Advertisement affected junk food consumption in $48(80.00 \%)$ subjects from Narendra and $32(53.33 \%)$ subjects from Krishinagar. Khongrangjem et al. (2018) in a study conducted on knowledge and practice of fast-food consumption among Pre-University students in Udupi Taluk, Karnataka, India reported that about 51 (31.87\%) of the participants had inadequate knowledge, 67 (41.88\%) of the participants had moderate knowledge and $42(26.25 \%)$ of the participants had adequate knowledge about the effect of fast-food consumption. 
Table 4 Frequency of junk food consumption among the subjects

$\mathbf{N}=\mathbf{1 2 0}$

\begin{tabular}{|c|c|c|c|}
\hline Sl. No & Frequency of consumption & Narendra & Krishinagar \\
\hline 1$)$ & Never & $3(5.00 \%)$ & $5(8.33 \%)$ \\
\hline 2$)$ & Occasionally & $7(11.67 \%)$ & $8(13.33 \%)$ \\
\hline 3$)$ & Once a month & $21(35.00 \%)$ & $17(28.33 \%)$ \\
\hline 4$)$ & Once a 15 days & $11(18.33 \%)$ & $10(16.67 \%)$ \\
\hline 5$)$ & Once a week & $7(11.67 \%)$ & $10(16.67 \%)$ \\
\hline 6$)$ & Alternate day & $5(8.33 \%)$ & $6(10.00 \%)$ \\
\hline 7$)$ & Daily & $6(10.00 \%)$ & $4(6.67 \%)$ \\
\hline & Total & 60.00 & 60.00 \\
\hline
\end{tabular}

Frequency (percentage)

Table 4 shows frequency of junk food consumption among the subjects. Majority of subjects from both rural Narendra $21(35.00 \%)$ and urban Krishinagar 17 (28.33\%) consumed junk food on monthly basis. Subjects from Narendra 11 (18.33 $\%)$ consumed junk food once a 15 days. Subjects from Krishinagar $10(16.67 \%)$ consumed of junk food once a week and once a 15 days. Mirkarimi et al. (2016) stated that the adolescents consumed fast food on monthly basis. Malushte and Hedeoo (2016) in a study conducted on buying behaviour of fast foods among adolescents aged 16-19 years reported that majority of respondents that is 64.5 per cent consumed fast foods 1-2 times followed by 26.5 percent consuming 3-4 times and 5 per cent more than 5 times per week.

Table 5 Commonly consumed junk food consumption among the subjects

\begin{tabular}{|c|c|c|}
\hline Sl. No & School & Junk foods \\
\hline $\mathbf{1 .}$ & Narendra & Chips, namkeens, sweets and other items like toffees, candies \\
\hline $\mathbf{2 .}$ & Krishinagar & Chips, namkeens, coloured ice candy and toffees \\
\hline
\end{tabular}

Table 5 shows commonly consumed junk food consumption among the subjects. Subjects from rural Narendra consumed deep fried items like chips, namkeens, sweets and other items like toffees, candies whereas those from urban Krishinagar consumed chips, namkeens, coloured ice candy and toffees. Asundi and Chimmad (2012) noted that many rural people consumed unbranded junk food. Malushte and Hedeoo (2016) stated that advertisements and peer group influence junk food consumption.

\section{CONCLUSION}

Majority of subjects both from rural and urban consumed junk foods on monthly basis. Commonly consumed junk foods were deep fried items like chips, namkeens, sweets and other items like toffees, candies and coloured ice candies which were easily available in local area. Though most of the subjects from both schools were aware about junk food, their knowledge regarding composition and effects were limited. Hence there is a need create awareness and impart knowledge regarding junk food and its effect on health among school children.

\section{REFERENCES}

1. Asgary, S., Nazari, B., Sarrafzadegan, N. and Parkhideh, S., 2009., Evaluation of fatty acid content of some Iranian fast foods with emphasis on trans fatty acids. Asia Pac. J. Clin. Nutr., 18: 187-92.

2. Asundi, C. R. and Chimmad, B., 2016, Scenario of junk food consumption in rural north Karnataka. M.H.Sc thesis., University of Agricultural Sciences, Dharwad, Karnataka.

3. Kaushik, J. S., Narang, M. and Parakh, A., 2011, Fast food consumption in children, Indian Pediatr., 48:124-128.

4. Khongrangjem, T., Sushma, D. and Kumar, S., 2018, A study to assess the knowledge and practice of fast-food consumption among PreUniversity students in Udupi Taluk, Karnataka, India. Clin. Epid. Global Health., 6:172-175.

5. Malushte, R. S. and Hedeoo, R. P., 2016, Appealing food environments provided by fast food industry influencing the eating and buying behaviour of fast foods among adolescents aged 16-19 years. Nutri. Diet., 5(2):44-48.

6. Mirkarimi, K., Mansourian, M., Kabir, M. J., Ozouni, D. R. B., Eri, M. and Hosseini, S. G., 2016, Fast food consumption behaviours in highschool students. Int. J. Pediatr., 4(7): 2131-2142.

7. Printice, A. M. and Jebb, S, A., 2003, Fast foods, energy density and obesity: A possible mechanistic link. Obesity Rev., 4:187-194. 